\title{
Effect of Media, Temperature and Light Wavelength on the Growth of Curvularia lunata Causing Curvularia Leaf Spot of Maize
}

\author{
Divya Bhatt* and Pradeep Kumar
}

Department of Plant Pathology, GBPUA and T, Pantnagar - 263145 (Uttarakhand), India

*Corresponding author

\section{A B S T R A C T}

\section{Key words \\ Curvularia lunata, \\ Media, Temperature, \\ Light wavelength, Maize \\ Article Info \\ Accepted: \\ 16 August 2018 \\ Available Online: \\ 10 September 2018}

The effect of different media (Oat meal agar, Corn meal agar, Czapeck's Dox agar, Potato dextrose agar, Richard's synthetic agar and $2 \%$ malt extract agar) on light wavelengths (red, yellow, blue, green) and temperatures $\left(10,15,20,25,30,35^{\circ} \mathrm{C}\right.$ ) were examined to determine optimal conditions for mycelial growth of Curvularia lunata causing Curvularia leaf spot of maize under in vitro conditions. Amongst media under different temperatures, maximum mycelial growth $(88.17 \mathrm{~mm})$ was found in Potato dextrose agar $30^{\circ} \mathrm{C}$ followed $(84.33 \mathrm{~mm})$ by Potato dextrose agar at $25^{\circ} \mathrm{C}$. Similarly, the effect of media and wavelength, maximum radial growth was observed on Oat meal agar in blue light (86.33 $\mathrm{mm})$.

\section{Introduction}

Maize (Zea mays L.) is a valuable resourceful cereal crop which contributes to food security in most of the developing countries. In India, maize is emerging as third most important crop after rice and wheat. It is cultivated throughout the year in different parts of the country for diverse purposes as well as grain, fodder, green cobs, sweet corn, baby corn, pop corn and industrial purposes etc. (Barupal and Sharma 2015). Maize is the basic raw material required for manufacturing starch and has 6065 per cent starch content, hence cannot be easily substituted by other commodities. India is the largest producer of Maize in the world, with 22.57 lakh MT during the year 2015-16 (APEDA, 2016). Maize cultivation is affected by insects, diseases, weeds and some abiotic factors. In context of biotic factors huge amount of loss is encountered in several economically important crop plants by the plant parasitic fungi (Sarma, 2006). Curvularia leaf spot caused by Curvularia lunata is one of the most important diseases emerging since last few years. This disease damages most as compared to other leaf spots or leaf blight of corn with clear visible symptoms exhibiting small chlorotic spots that expand into a round or oval-shaped lesion surrounded by a wide translucent straw yellow coloured halo (Rao and William, 1978). Several lesions when coalesce together leads to the formation of leaf necrosis. Curvularia species being plant parasites are mostly found in subtropical and tropical areas of the world (Smiley et al., 
2005). Therefore, experiments were planned to observe the effects of culture media, temperatures and light wavelengths on mycelial growth and of Curvularia lunata.

\section{Materials and Methods}

\section{Effect of different media and temperatures on radial growth of Curvularia lunata}

Effect of different temperature viz; 10, 15, 20, $25,30,35^{\circ} \mathrm{C}$ on the growth of fungus was studied on different medium viz; Oat meal agar, Corn meal agar, Czapeck's Dox agar, Potato dextrose agar, Richard's synthetic agar and 2\% malt extract agar. The sterilized medium was poured into sterilized petri plates and after solidification the plates were centrally inoculated with $5 \mathrm{~mm}$ disc of the fungus and incubated at different temperatures with three replications. Colony diameter was measured up to 7 days of incubation.

Effect of different media and light wavelengths on radial growth of Curvularia lunata

Effect of different wavelengths of light viz; red, yellow, blue, green of Curvularia lunata was studied on different medium viz; Oat meal agar, Corn meal agar, Czapeck's Dox agar, Potato dextrose agar, Richard's synthetic agar and 2\% malt extract agar. The sterilized medium was poured into sterilized petri plates and after solidification the plates were centrally inoculated with $5 \mathrm{~mm}$ disc of the fungus and incubated at $28 \pm 2^{\circ} \mathrm{C}$ with three replications. For this study, four different wooden cuboidal chambers were made and different coloured cellophane sheets were wrapped inside the box, source of light was LED bulb. The wavelengths exhibited were of range: $400-500 \mathrm{~nm}$ (blue); 480-540 nm (green); 500-700 nm (yellow); 600-700 nm (red). Colony diameter was measured up to 7 days of incubation.

\section{Results and Discussion}

Effect of different media and temperatures on radial growth of Curvularia lunata

Temperature being one of the most essential environmental factor influencing plant's development in natural and diseased surroundings and also growth rate of plants at $27^{\circ} \mathrm{C}$ is more as compared to $21^{\circ} \mathrm{C}$, hence for pathogen suitable temperature is essential for estabilishing host-pathogen relationship and finally causing disease. Results revealed (Table 1), at $10^{\circ} \mathrm{C}$ maximum growth of the fungus was reported in Corn meal agar (19.00 $\mathrm{mm})$ followed by $2 \%$ malt extract agar $(17.33$ $\mathrm{mm}$ ) while no growth was found in Richard's synthetic agar. At $15^{\circ} \mathrm{C}$ maximum growth of the fungus was reported in Richard's synthetic agar $(55.17 \mathrm{~mm})$ followed by Czapeck's dox agar $(49.17 \mathrm{~mm})$ and Oat meal agar $(41.83 \mathrm{~mm})$ and the minimum was recorded in $2 \%$ malt extract agar $(30.33 \mathrm{~mm})$. At $20^{\circ} \mathrm{C}$ maximum growth was supported by $2 \%$ malt extract agar $(31.67 \mathrm{~mm})$ followed by Oat meal agar $(22.67 \mathrm{~mm})$ and Potato dextrose agar $(20.00 \mathrm{~mm})$ while least growth was recorded in Richard's synthetic agar $(11.17 \mathrm{~mm})$.

At $25^{\circ} \mathrm{C}$ maximum growth was supported by Potato dextrose agar $(84.33 \mathrm{~mm})$ that was at par with Richard's synthetic agar $(82.67 \mathrm{~mm})$ followed by corn meal agar $(77.50 \mathrm{~mm})$ while the minimum was recorded in $2 \%$ malt extract agar $(67.83 \mathrm{~mm})$. At $30^{\circ} \mathrm{C}$ maximum growth was supported by Potato dextrose agar (88.17 $\mathrm{mm})$ followed by Oat meal agar $(80.50 \mathrm{~mm})$ and Czapeck's dox agar $(78.17 \mathrm{~mm})$ while the minimum was recorded in $2 \%$ malt extract agar $(55.33 \mathrm{~mm})$. At $35^{\circ} \mathrm{C}$ maximum growth of the fungus was reported in Richard's synthetic agar $(24.00 \mathrm{~mm})$ followed by Czapeck's dox agar $(20.33 \mathrm{~mm})$ and Potato dextrose agar $(18.00 \mathrm{~mm})$ while the minimum was recorded in $2 \%$ malt extract agar (14.33 $\mathrm{mm}$ ). 
Table.1 Effect of different media and temperatures on radial growth of Curvularia lunata

\begin{tabular}{|c|c|c|c|c|c|c|c|}
\hline \multirow[t]{3}{*}{ Sl. No. } & \multirow[t]{3}{*}{ Solid media } & \multicolumn{6}{|c|}{ Temperature $\left({ }^{0} \mathrm{C}\right)$} \\
\hline & & 10 & 15 & 20 & 25 & 30 & 35 \\
\hline & & \multicolumn{6}{|c|}{ Radial growth (mm) } \\
\hline 1 & Oat meal agar & 8.00 & 41.83 & 22.67 & 74.83 & 80.50 & 15.33 \\
\hline 2 & Corn meal agar & 19.00 & 36.50 & 17.00 & 77.50 & 71.67 & 16.67 \\
\hline 3 & Czapeck's dox agar & 14.17 & 49.17 & 15.00 & 76.00 & 78.17 & 20.33 \\
\hline 4 & Potato dextrose agar & 10.00 & 34.33 & 20.00 & 84.33 & 88.17 & 18.00 \\
\hline 5 & Richard's synthetic agar & 0.00 & 55.17 & 11.17 & 82.67 & 76.33 & 24.00 \\
\hline 6 & $2 \%$ malt extract agar & 17.33 & 30.33 & 31.67 & 67.83 & 55.33 & 14.33 \\
\hline \multicolumn{2}{|c|}{ CD (A) at $5 \%=2.38$} & \multicolumn{2}{|c|}{$\operatorname{SEM}(A) \pm=0.84$} & \multicolumn{3}{|c|}{ (A) $=$ for media } & \\
\hline CD (B) & at $5 \%=2.36$ & SEM (B & & \multirow{2}{*}{\multicolumn{3}{|c|}{$\begin{array}{l}(B)=\text { for temperature } \\
(A * B)=\text { for interaction }\end{array}$}} & \\
\hline \multicolumn{2}{|c|}{$\mathrm{CD}(\mathrm{A} * \mathrm{~B})$ at $5 \%=5.80$} & \multicolumn{2}{|c|}{$\operatorname{SEM}(A * B) \pm=2.05$} & & & & \\
\hline
\end{tabular}

Table.2 Effect of different media and light wavelengths on radial growth of Curvularia lunata at $28 \pm 2^{\circ} \mathrm{C}$

\begin{tabular}{|c|c|c|c|c|c|}
\hline \multirow{2}{*}{$\begin{array}{l}\text { Sl. } \\
\text { No. }\end{array}$} & \multirow[t]{2}{*}{ Solid media } & \multicolumn{4}{|c|}{ Radial growth (mm) } \\
\hline & & Red & Blue & Green & Yellow \\
\hline 1 & Oat meal agar & 56.67 & 86.83 & 52.67 & 61.33 \\
\hline 2 & Corn meal agar & 60.67 & 60.50 & 65.33 & 44.50 \\
\hline 3 & Czapeck's dox agar & 69.17 & 64.00 & 76.67 & 72.17 \\
\hline 4 & Potato dextrose agar & 49.33 & 40.67 & 51.00 & 51.17 \\
\hline 5 & Richard's synthetic agar & 57.33 & 56.33 & 64.33 & 40.17 \\
\hline 6 & $2 \%$ malt extract agar & 59.17 & 43.33 & 56.00 & 57.33 \\
\hline \multicolumn{2}{|c|}{$\begin{array}{l}\text { CD (A) at 5\%=2.26 } \\
\text { CD (B) at 5\%=1.85 } \\
C D(A * B) \text { at } 5 \%=4.52\end{array}$} & \multicolumn{3}{|c|}{$\begin{array}{l}\operatorname{SEM}(A)=0.79 \\
\operatorname{SEM}(B)=0.65 \\
\operatorname{SEM}(A * B)=1.59\end{array}$} & $\begin{array}{l}(A)=\text { for media } \\
(B)=\text { for light wavelength } \\
(A * B)=\text { for interaction }\end{array}$ \\
\hline
\end{tabular}

Thus, from this experiment it was found that maximum mycelium growth was supported at both 25 and $30^{\circ} \mathrm{C}$ in all the media evaluated. Also, at $25^{\circ} \mathrm{C}$ and $30^{\circ} \mathrm{C}$ maximum growth of Curvularia lunata was in PDA. The growth on PDA can be attributed to the potato starch which provides flourishing growth of most of the fungi while dextrose is ideal as a growth stimulant. The results obtained from this study is in accordance with the findings of Lal et al., (2014) that amongst solid media, potato dextrose agar media $(7.60 \mathrm{~cm})$ and Host extract agar $(6.73 \mathrm{~cm})$ were the best for fungus growth as well as for sporulation and that the fungus can grow up to temperature range of $15^{\circ}-37^{\circ} \mathrm{C}$. Similar were the findings of Rudha et al., (2008) that potato dextrose agar medium was best suited medium for the mycelial growth and sporulaion for Curvularia lunata.

Effect of different media and light wavelengths on radial growth of Curvularia lunata at $28 \pm 2^{\circ} \mathrm{C}$

Environmental light plays an important role in various organisms including fungus leading to stress conditions. Fungi sense light and try to adapt in a suitable niche inflicted by the harmful 
effects of light. Hence, different wavelengths of light were evaluated to study the growth and suitable media for pathogen survival. Results (Table 2) revealed, in red light maximum growth of the fungus was reported in Czapeck's dox agar $(69.17 \mathrm{~mm})$ followed by Corn meal agar $(60.67 \mathrm{~mm})$ and the minimum was recorded in Potato dextrose agar $(49.33 \mathrm{~mm})$. In blue light maximum growth of the fungus was reported in Oat meal agar $(86.83 \mathrm{~mm})$ followed by Czapeck's dox agar $(64.00 \mathrm{~mm})$ and the minimum was recorded in Potato dextrose agar $(40.67 \mathrm{~mm})$. In green light maximum growth of the fungus was reported in Czapeck's dox agar $(76.67 \mathrm{~mm})$ followed by Corn meal agar $(65.33$ $\mathrm{mm}$ ) and the minimum was recorded in Potato dextrose agar $(51.00 \mathrm{~mm})$. In yellow light maximum growth of the fungus was reported in Czapeck's dox agar $(72.17 \mathrm{~mm})$ followed by Oat meal agar $(61.33 \mathrm{~mm})$ and the minimum was recorded in Richard's synthetic agar (40.17 $\mathrm{mm})$. Thus, from this experiment it was found that blue light (450-495 $\mathrm{nm}$ ) best supported the pathogen survival in oat meal agar $(86.83 \mathrm{~mm})$ and this may attributed to the pathogen's survival in host as plants in shade absorb blue to near UV wavelength light and also to oat meal agar as it is a good source of carbon, nitrogen, proteins and various nutrients. Since no previous work was done to study the effect wavelength of light on growth of the test fungus so comparison was made with other pathogens. The results obtained from this study were supported by the findings of Linden et al., (1997) who reported that light affects fungi in various ways like conidiation in Neurospora crassa. Similar were the findings of Schumacher (2017) who also reported the effect of light on Botrytis cinerea. Present study finding concludes that the $C$. lunata can grow various sources of media, different sources of nitrogen and wide range of temperature. Studied range of temperature could be utilized for epidemiological study and accordingly management strategies could be developed for managing this disease.

\section{References}

APEDA 2016. Ministry of Commerce and Industry, Government of India.

Barupal, T. and Sharma, K. 2015. Review: Plant Extract a Novel for Agriculture. Research Journal of Pharmaceutical, Biological and Chemical Sciences 6(2): 936.

Lal, M., Ali, M., Kumar, S., Singh, V. and Khan, A. 2014. Effect of media, nitrogen sources and temperature on the growth and sporulation of Curvularia lunata causing Curvularia leaf spot of blackgram. Bioscan 9(3): 1197-1199.

Linden, H., Ballario, P. and Macino, G. 1997. Blue light regulation in Neurospora crassa Fungal Genet. Biol., 22: 141-150.

Rao, K.N. and William, R.J. 1978. Proc. Int. Workshop on sorghum diseases, ICRISAT, Hyderabad.

Rudha, S.A., Mezhir, M.N. and Abbas, A.B. 2008. The effect of some chemicals and bio-factors in the growth and sporulation of Curvularia lunata using culture media. Basrah J. Agrci. Sci. 21(2): 135-150.

Sarma, P.U. 2006. Fungal Biochemistry and Applications. National science digital library at NISCAIR, India.

Schumacher, J. 2017. How light affects the life of Botrytis. Fungal Genetics and Biology 106: $26-41$

Smiley, R.W., Dernoeden, P.H. and Clarke, B.B. 2005. Compendium of turfgrass diseases. 3rd Ed. American Phytopathological Society., St. Paul, MN.

\section{How to cite this article:}

Divya Bhatt and Pradeep Kumar. 2018. Effect of Media, Temperature and Light Wavelength on the Growth of Curvularia lunata Causing Curvularia Leaf Spot of Maize. Int.J.Curr.Microbiol.App.Sci. 7(09): 2227-2230. doi: https://doi.org/10.20546/ijcmas.2018.709.275 